\title{
IMPORTANCE PERFORMANCE ANALYSIS TERHADAP PELAYANAN PERMINTAAN INFORMASI DEBITUR INDIVIDUAL (IDI) HISTORIS PADA KANTOR PERWAKILAN BANK INDONESIA KALIMANTAN SELATAN
}

\author{
Ilma Mahdiya \\ Rohana Faridah
}

Fakultas Ekonomi dan Bisnis Islam UIN Antasari

Alamat Email: Ilmamahdiva12@gmail.com

\begin{abstract}
This research was motivated by the existence of services provided by Bank Indonesia to the public, especially bank debtor customers, namely the Historical Request for Individual Debtor Information (IDI). As a state institution that provides services to the community, especially debtor customers, of course Bank. Indonesia employees must provide the best or best service to the recipients of these services. So far the Bank. Indonesia Representative Office of South Kalimantan Province does not yet have service standards, for which officers must be able to pay attention to expectations that are considered important for the community. The formulation of the problem in this study is how is the quality of service requests for Historical Individual Debtor Information (IDI) at the Bank Indonesia Representative Office of South Kalimantan Province using the Importance Performance Analysis method? This research is in the form of field research with a quantitative descriptive approach. This research is located at the Bank. Indonesia Representative Office of South Kalimantan Province having its address at Jalan Lambung Mangkurat No.15, Banjarmasin City. Data collection techniques used were questionnaires. The results of this study indicate that by using the Importance Performance Analysis method it is known that the quality of service requests for Historical Individual Debtor Information (IDI) at the Bank Indonesia Representative Office of South Kalimantan Province do not meet the prime service criteria or best because overall there is a gap between the average level of performance / performance with an importance value. Using Cartesian diagrams, there are important or priority factors to eliminate gaps to improve service quality. Service factors that need to be prioritized for improvement are Item 21 (Fast service) and Item 51 (Equipment that supports adequate convenience and comfort).
\end{abstract}

Abstrak: Penelitian ini dilatar belakangi karena adanya pelayanan yang diberikan oleh Bank Indonesia kepada masyarakat khususnya nasabah debitur perbankan, yaitu Pelayanan Permintaan Informasi Debitur Individual (IDI) Historis. Sebagai lembaga negara yang memberikan pelayanan kepada masyarakat khususnya nasabah debitur, tentunya pegawai Bank Indonesia harus memberikan pelayanan yang terbaik atau prima kepada penerima pelayanan tersebut. Selama ini Kantor Perwakilan Bank Indonesia Provinsi Kalimantan Selatan belum memiliki standar pelayanan, untuk itu petugasnya harus mampu memperhatikan harapan yang dianggap penting bagi masyarakat. Rumusan masalah dalam penelitian ini adalah Bagaimana kualitas pelayanan permintaan Informasi Debitur Individual (IDI) Historis Pada Kantor Perwakilan Bank Indonesia Provinsi Kalimantan Selatan menggunakan metode Importance Performance Analysis?. Penelitian ini berupa penelitian lapangan (field research) dengan pendekatan deskriptif kuantitatif. Penelitian ini berlokasi di Kantor Perwakilan Bank Indonesia Provinsi Kalimantan Selatan yang beralamat di Jalan Lambung Mangkurat No.15, Kota Banjarmasin. Teknik pengumpulan data yang digunakan adalah dengan kuesioner. Hasil dari penelitian ini menunjukan bahwa dengan menggunakan metode Importance Performance Analysis diketahui kualitas pelayanan permintaan Informasi Debitur Individual (IDI) Historis Pada Kantor Perwakilan Bank Indonesia Provinsi Kalimantan Selatan belum memenuhi kriteria pelayanan prima atau terbaik karena secara keseluruhan terdapat kesenjangan antara nilai rata-rata tingkat kinerja/performance dengan nilai rata-rata tingkat kepentingan/importance. Dengan menggunakan diagram Cartesius terlihat faktor-faktor yang penting atau yang menjadi prioritas untuk menghilangkan kesenjangan sehingga meningkatkan kualitas pelayanan. Faktor-faktor pelayanan yang perlu diprioritaskan untuk diperbaiki adalah Item 21 (Pelayanan yang cepat) dan Item 51 (Peralatan penunjang kemudahan dan kenyamanan yang memadai).

Kata Kunci: Importance Performance Analysis, pelayanan.

\section{Pendahuluan}

Program pembangunan ekonomi nasional haruslah dilaksanakan secara transparan dan akuntabel yang berpedoman pada prinsip demokrasi ekonomi sesuai dengan Pancasila dan Undang-Undang Dasar 1945. Untuk mencapai tujuan tersebut, perlu didukung oleh tata kelola pemerintahan yang baik secara terusmenerus melakukan reformasi terhadap setiap komponen dalam sistem perekonomian nasional.

Salah satu komponen penting dalam sistem perekonomian nasional adalah sistem keuangan dan 
seluruh kegiatan jasa keuangan yang menjalankan fungsi intermediasi bagi berbagai kegiatan produktif di dalam perekonomian nasional. ${ }^{1}$

Sistem keuangan suatu negara adalah tatanan dalam perekonomian suatu negara yang memiliki peran utama menyediakan fasilitas jasa bidang keuangan oleh lembaga-lembaga keuangan dan lembaga penunjang lainnya. ${ }^{2}$

Lembaga keuangan yang paling penting dalam sistem keuangan adalah bank sentral, yaitu agen pemerintah yang bertanggung jawab dan independen dalam pembentukan kebijakan moneter. Kebijakan moneter mencakup manajemen tingkat bunga dan jumlah uang yang beredar. Pemahaman tentang pembentukan dan pengaruh kebijakan moneter 2 M.. diperlukan bagi aktivitas lembaga keuangan. Tanpa memahami pembentukan dan pengaruh kebijakan moneter akan menurunkan produktivitas lembaga keuangan. ${ }^{3}$

Secara garis besar lembaga keuangan yang merupakan subsistem dari sistem keuangan dapat dibagi menjadi dua kelompok yaitu lembaga keuangan bank, atau sering kali hanya disebut sebagai bank, dan lembaga keuangan bukan bank. Baik yang melaksanakan kegiatan usaha memberikan jasa berdasarkan cara konvensional (bunga) maupun berdasarkan prinsip syariah (bagi hasil) yang mengacu pada hukum Islam.

Lembaga keuangan bukan bank terdiri dari lembaga-lembaga keuangan yang fungsi dan kegiatan pokoknya berbeda dengan bank, misalnya asuransi, dana pensiun, pegadaian, leasing (sewa guna usaha), dan factoring (anjak piutang). ${ }^{4}$ Dalam kegiatan usahanya lembaga keuangan bukan bank tidak diperkenankan menghimpun dana secara langsung dari masyarakat dalam bentuk simpanan tetapi harus melalui kontrak tertentu untuk meminimalkan risiko. ${ }^{5}$

Bank merupakan lembaga keuangan yang memiliki fungsi intermediasi yang menjembatani kepentingan pihak yang kelebihan dana dan pihak yang membutuhkan dana. Fungsi intermediasi dapat berjalan dengan baik apabila kedua belah pihak memiliki kepercayaan terhadap bank. Oleh

1 H.Veithzal Rivai, Financial Institution Management (Manajemen Kelembagaan Keuangan) (Jakarta: Rajawali Pers, 2013), hlm. 583.

${ }^{2}$ Sulhan dan Ely Siswanto, Manajemen Bank Konvensional dan Syariah (Malang: UIN-Malang Press, 2008), hlm. 6

3 Jonni Manurung, Ekonomi Keuangan dan Kebijakan Moneter (Jakarta: Salemba Empat, 2009), hlm. 7.

4 H. Veithzal Rivai, Commercial Bank Management: Manajemen Perbankan dari Teori ke Praktik (Jakarta: Rajawali Pers, 2013), hlm. 95. karena itu, bank sering juga disebut sebagai lembaga kepercayaan.

Sebagai lembaga intermediasi yang menghubungkan penabung ke peminjam, perbankan pasti akan menghadapi berbagai risiko yang dapat mengganggu jalannya kegiatan usaha. Usaha perbankan adalah usaha yang memiliki risiko yang tinggi baik dari aspek penarikan dana maupun dari aspek penyaluran dana. ${ }^{6}$

Apalagi situasi bisnis perbankan saat ini mengalami perkembangan yang sangat pesat, dan diiringi dengan peningkatan persaingan antar bank, membuat risiko perbankan menjadi semakin komplek dan sangat rentan mengalami kebangkrutan.

Dalam suatu sistem perbankan yang bersifat sistemik, kebangkrutan suatu bank akan mengakibatkan terganggunya operasional bankbank lainnya karena sistem perbankan bersifat interdependen. ${ }^{7}$ Karena sebagian besar dana di perbankan adalah dana masyarakat, jika bank mengalami kebangkrutan, masyarakat akan dirugikan dan menghilangkan kepercayaan masyarakat terhadap bank. Lebih buruk lagi akan berdampak pada perekonomian negara. Lindgren mengkaji bahwa negaranegara yang kondisi perekonomiannya tidak baik dikarenakan buruknya sektor perbankan. ${ }^{8}$ Risiko dalam konteks perbankan merupakan suatu kejadian potensial, baik yang dapat diperkirakan (anticipated) maupun yang tidak dapat diperkirakan (unanticipated) yang berdampak negatif terhadap pendapatan dan permodalan bank. Risiko-risiko tersebut tidak dapat dihindari, tetapi dapat dikelola dan dikendalikan.

Dengan demikian, dibutuhkan praktik tata kelola bank yang sehat (good corporate governance) dan penerapan manajemen risiko yang meliputi pengawasan aktif pengurus bank, kebijakan, prosedur dan penetapan limit risiko, proses identifikasi, pengukuran, sistem informasi, dan pengendalian risiko, serta sistem pengendalian intern. ${ }^{9}$

Sejak 2006, dalam rangka memperlancar proses penyediaan dana untuk mendorong pembangunan ekonomi dan penerapan manajemen

5 M. Sulhan dan Ely Siswanto, Manajemen Bank Konvensional dan Syariah (Malang: UIN-Malang Press, 2008), hlm. 8

${ }^{6}$ Julius R. Latumaerissa, Bank dan Lembaga Kenangan Lain (Jakarta: Salemba Empat, 2011), hlm. 142.

${ }^{7}$ M. Sulhan dan Ely Siswanto, op. cit., hlm. 18.

${ }^{8}$ Ibid., hlm. 17

9 H. Veithzal Rivai, Commercial Bank Management: Manajemen Perbankan dari Teori ke Praktik (Jakarta: Rajawali Pers, 2013), hlm. 549. 
risiko, Bank Indonesia sebagai bank sentral telah mengatur dan mengembangkan penyelenggaraan sistem informasi antar bank maupun lembaga lain di bidang keuangan. Salah satunya membuat sistem data base debitur bersama atau yang dikenal dengan sebutan Sistem Informasi Debitur.

Berdasarkan Peraturan Bank Indonesia Nomor 9/14/PBI/ 2007 tentang Sistem Informasi Debitur, Sistem Informasi Debitur adalah sistem yang menyediakan informasi Debitur yang merupakan hasil olahan dari Laporan Debitur yang diterima oleh Bank Indonesia.

Penyelenggaraan Sistem Informasi Debitur dimaksudkan untuk membantu pelapor dalam memperlancar proses penyedian dana mempermudah penerapan manajemen risiko, dan membantu bank dalam melakukan identifikasi kualitas Debitur untuk pemenuhan ketentuan yang berlaku. Pelapor adalah bank umum, BPR, penyelenggara kartu kredit selain bank, dan lembaga keuangan bukan bank. Cakupan informasi debitur meliputi antara lain: identitas debitur, pemilik dan pengurus, fasilitas penyediaan dana yang diberikan, agunan, penjamin dan kolektabilitas. ${ }^{10}$

Hingga Januari 2016, menurut statistik perbankan yang dikeluarkan oleh Bank Indonesia, jumlah debitur yang dicatat oleh Biro Informasi Debitur sebagai berikut:

Tabel 1

Data Perkembangan Jumlah Debitur Di Indonesia Hingga Januari 2016 (Ribu Orang)

\begin{tabular}{|c|c|c|c|c|c|c|}
\hline \multicolumn{5}{|c|}{2015} & 2016 & \multirow[t]{2}{*}{ Keterangan } \\
\hline Ags & September & Oktober & November & Desember & Januari & \\
\hline 76.038 & 76.654 & 77.149 & 77.643 & 78.197 & 78.685 & $\begin{array}{c}\text { Bank } \\
\text { Umum }\end{array}$ \\
\hline 8.557 & 8.620 & 8.681 & 8.754 & 8.840 & 8.926 & $\mathrm{BPR} / \mathrm{S}$ \\
\hline 1.755 & 1.755 & 1.774 & 1.796 & 1.845 & 1.892 & LKNB \\
\hline 86.32 & 87.03 & 87.605 & 188.196 & 88.883 & 89.504 & Total \\
\hline
\end{tabular}

Dalam pelaksanaanya, setiap bulan pihak bank atau anggota Sistem Informasi Debitur lainnya melaporkan data transaksi, dan informasi-informasi lain nasabahnya yang dalam hal ini debiturnya secara online ke Bank Indonesia, sehingga setiap bulan datanya akan selalu dalam keadaan ter-update di server Bank Indonesia. Seluruh data dari bank atau anggota Sistem Informasi Debitur lainnya di konsolidasi di server Bank Indonesia yang lalu menghasilkan output seperti BI Checking dan data lainnya.

Pada dasarnya yang lazim melakukan BI Checking adalah pihak Bank yang mendapat pengajuan kredit dari nasabah atau calon nasabahnya. Selain pihak bank, warga juga bisa melakukan BI Checking sendiri. Bertujuan untuk dokumentasi pribadi, mengonfirmasi apakah pihak bank telah melakukan pelaporan data yang sesuai ke Bank Indonesia dengan yang sebenarnya terjadi. Hal ini berfungsi untuk melakukan pengecekan ketika akan mengajukan pinjaman lagi, sehingga tidak mengalami hambatan, khususnya yang terkait dengan BI Checking. Bukti print out BI Checking yang bersumber dari data base Sistem Informasi Debitur yang dikelola oleh Bank Indonesia tersebut,

${ }^{10}$ Ibid., hlm. 43. berisikan data yang menyangkut informasi identitas debitur dan kondisi fasilitas kredit/pembiayaan yang diterima meliputi plafon, baki debet, jangka waktu pembiayaan, dan kondisi (historis) pembayaran selama 24 bulan terakhir sejak posisi data dalam BI Checking di up date. Data tersebut tersaji per individu, bukan dalam bentuk list (daftar), oleh karena itu disebut Informasi Debitur Individual (IDI) Historis. ${ }^{11}$

Jika mengacu kepada peraturan Bank Indonesia yaitu Peraturan Bank Indonesia Nomor 9/14/PBI/ 2007 tentang Sistem Informasi Debitur, di dalam pasal 24 dijelaskan bahwa nasabah debitur dapat meminta informasi Debitur kepada Bank Indonesia atau bisa juga kepada Pelapor yang memberikan Penyediaan Dana kepada debitur tersebut. Dalam prakteknya, banyak pelapor yang tidak memberikan pelayanan penyediaan data informasi Debitur dan menyarankan kepada nasabah debitur untuk datang langsung ke Bank Indonesia. Dengan demikian, pelayanan permintaan Informasi Debitur Individual (IDI) Historis saat ini hanya terlaksana di kantor-kantor Bank Indonesia, padahal

11 Pulo Siregar, Bebaskan utangmu 27 Studi Kasus Menyelesaikan Utang Secara Legal (Jakarta: Kompas Gramedia, 2014), hlm. 244-246 
seharusnya bisa saja dilakukan di bank-bank atau lembaga non bank lainnya.

Pelayanan permintaan Informasi Debitur Individual (IDI) Historis khususnya di Kalimantan Selatan berada dibawah naungan Kantor Perwakilan Bank Indonesia yang dijalankan oleh Tim Data Statistik Ekonomi Keuangan Daerah. Berdasarkan Surat Edaran Nomor 15/62/Intern tentang Organisasi Kantor Perwakilan Dalam Negari, tugas dari Tim Data Statistik Ekonomi Keuangan Daerah tidak hanya memberikan layanan Informasi Debitur Individual (IDI) Historis, melainkan juga melakukan survei dan liaison terkait perekonomian daerah serta menyusun absensi Laporan Bulanan Bank dan BPR. Hal ini bisa saja mengakibatkan layanan Informasi Debitur Individual (IDI) Historis tidak maksimal dan mendapatkan penilaian yang buruk dari nasabah debitur.

Sebagai lembaga negara yang memberikan pelayanan kepada masyarakat khususnya nasabah debitur, tentunya pegawai Bank Indonesia harus memberikan pelayanan yang terbaik atau prima kepada penerima pelayanan tersebut.

Pelayanan prima dapat diwujudkan jika ada standar pelayanan minimal. Jika suatu instansi belum memiliki standar pelayanan, maka pelayanan disebut prima jika mampu memuaskan penerima layanan atau sesuai dengan harapan penerima layanan. Selama ini Kantor Perwakilan Bank Indonesia Provinsi Kalimantan Selatan belum memiliki standar pelayanan, untuk itu petugasnya harus mampu memperhatikan harapan yang dianggap penting bagi masyarakat.

Harapan pelanggan dibentuk oleh pengalaman masa lampaunya, setelah menerima jasa suatu perusahaan penyedia jasa, mereka akan membandingkan jasa yang dirasakannya dengan jasa yang diharapkannya. Jika jasa yang dirasakannya berada di bawah jasa yang diharapkan, pelanggan tidak berminat lagi pada penyedia jasa tersebut. Namun apabila sebaliknya maka mereka akan kembali lagi menggunakan penyedia jasa tesebut. ${ }^{12}$

Jika pelayanan yang diberikan oleh pegawai mendapat penilaian baik dan membuat masyarakat merasa senang karena telah sesuai dengan harapan (kepentingan) yang diinginkan, maka akan mendorong masyarakat menjadi tidak enggan untuk

12 Hendra Teguh dan Ronny A. Rusli, Manajemen Pemasaran, Manajemen Pemasaran jilid 2 terjemahan dari buku Philip Kotler, Marketing Managemet (Jakarta: Prenhallindo, 1997), hlm. 92.

${ }^{13}$ Helti Marini Sipayung, BI Dorong Pemanfaatan Sistem Informasi Debitur (Bengkulu: Antara Bengkulu, memanfaatkan Sistem Informasi Debitur. Terlebih Bank Indonesia sendiri, mendorong utamanya kepada para debitur untuk memanfaatkan Sistem Informasi Debitur dalam perekonomian agar meningkatkan pertumbuhan ekonomi, stabilitas keuangan, sistem perkreditan yang sehat dan efisien. $^{13}$

Konsep Islam juga telah mengajarkan bahwa dalam memberikan layanan dari usaha yang dijalankan baik itu berupa barang atau jasa jangan memberikan yang buruk atau tidak berkualitas, melainkan hendaknya yang berkualitas dan bagus kepada orang lain. Allah SWT berfirman dalam alQur'an surah al-Baqarah ayat 267:

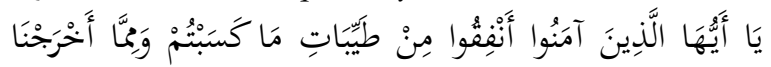

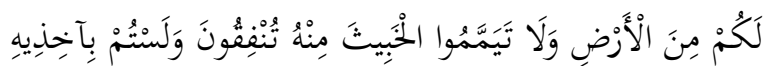

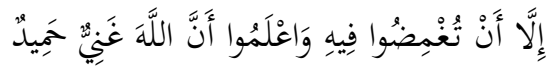

Artinya: "Hai orang-orang yang beriman, nafkabkeanlah (di jalan Allab) sebagian dari hasil usahamu yang baik-baik dan sebagian dari apa yang Kami keluarkan dari bumi untuk kamu. dan janganlah kamu memilih yang buruk-buruk lalu kamu menafkabkan daripadanya, Padahal kamu sendiri tidak mau mengambilnya melainkan dengan memincingkan mata terbadapnya. dan ketabuilah, babwa Allah Maha Kaya lagi Maha Terpuji." 14

Dalam ayat tersebut dijelaskan bahwa bagaimana seharusnya sikap seseorang dalam menafkahkan hartnaya di jalam Allah. Hendaknya menafkahkan yang baik dan berkualitas bukan yang buruk dan tidak berkualitas yang dia sendiri saja bahkan tidak menyukai dan menginginkannya. Oleh karena itu dalam memberikan jasa kepada orang lain kita harus memberikan pelayanan kepada orang lain dengan pelayanan yang baik dan berkualitas.

Berdasarkan uraian diatas, maka penulis merasa tertarik untuk melakukan penelitian lebih lanjut terkait pelayanan permintaan Informasi Debitur Individual (IDI) Historis dengan menggunakan metode Importance Performance Analysis. Konsep analisis Importance dan Performance berasal dari konsep SERVQUAL. Intinya, sebagaimana yang dijelaskan oleh Parasuraman, tingkat kepetingan pelanggan

2015).http://m.antarabengkulu.com/berita/31739/bid orong-pemanfaatan-sistem-informasi-debitur Maret 2016).

${ }^{14}$ Kementrian Agama RI, Ummul Mukminin AlQur'an dan Terjemah untuk, wanita (Jakarta:Wali, 2012), hlm. 45. 
(customer expectation) diukur kaitannya dengan apa yang seharusnya dikerjakan oleh perusahaan agar menghasilkan produk atau jasa yang berkualitas tinggi. Dalam konsep ini, istilah expectation (harapan) diganti dengan importance atau tingkat kepentingan menurut pelanggan. ${ }^{15}$ Dari berbagai persepsi, nantinya kita dapat merumuskan tingkat kepentingan yang paling dominan. Selanjutnya, kita dapat mengaitkan variabel kepentingan ini dengan kenyataan yang dirasakan oleh pelanggan istilah lainnya performance.

Adapun variabel penentu kualitas pelayanan yang digunakan dalam penelitian penulis ada lima macam yaitu: Daya Tanggap (Responsive), Kehandalan (Reliability), Jaminan (Assurance), Perhatian (Empathy) dan Bukti Fisik (Tangibles). ${ }^{16}$

Penelitian ini akan disusun penulis menjadi sebuah Karya Tulis Ilmiah dengan judul: Importance Performance Analysis Terhadap Pelayanan Permintaan Informasi Debitur Individual (IDI) Historis Pada Kantor Perwakilan Bank Indonesia Provinsi Kalimantan Selatan.

\section{Landasan Teori}

\section{A. Jasa}

Menurut Kotler jasa adalah sebagai tindakan atau kegiatan yang dapat ditawarkan oleh suatu pihak kepada pihak lain yang pada dasarnya bersifat tidak berwujud fisik dan tidak menghasilkan kepemilikan sesuatu. ${ }^{17}$ Jasa merupakan jenis bisnis yang menjual bantuan dan keahlian, produknya tidak berwujud. ${ }^{18}$ Produksinya bisa berhubungan dengan produk fisik maupun tidak (jasa pelengkap produk atau jasa murni). ${ }^{19}$ Maksudnya jasa tidak memiliki wujud dan tidak dapat dilihat dengan panca indera. Jika dikaitkan dengan kegiatan menjual dan aspek kepemilikan maka penjual jasa dengan aktifitas menjualnya tidak memberikan sesuatu kepada pembeli jasa untuk dimiliki namun hanya manfaat dan maslahat yang diberikan kepada pembeli jasa.

\section{B. Konsep Pelayanan}

Pelayanan merupakan terjemahan dari istilah service dalam bahasa inggris. Service is the activity of working for other people or for a community or

\footnotetext{
${ }^{15}$ Freddy Rangkuti, Measuring Customer Statisfaction Teknik Mengukur dan Strategi Meningkatkan Kepuasan Pelanggan (Jakarta : Gramedia Pustaka Utama, 2002), hlm. 109-110. 16 J. Supranto, Pengukuran Tungkat Kepausan Pelanggan (Jakarta: Rineka Cipta, 2006), hlm.3 .

${ }^{17}$ Fandi Tjiptono dan Gregorius Chandra, Service, Quality \& Statisfaction (Yogyakarta: Andi, 2005), hlm. 16.

${ }^{18}$ Susanto, Kamus Istilab Pemasaran (Jakarta: PT Gramedia 2002), hlm. 970.
}

organization. ${ }^{20}$ Yang artinya Layanan adalah kegiatan bekerja untuk orang lain atau untuk masyarakat atau organisasi.

Atep Adya Brata menyatakan bahwa service adalah singkatan yang mempunyai arti sebagai berikut:

1. S (Self awareness): Menanamkan kesadaran diri sehingga dapat memahami posisi, agar memberikan pelayanan dengan cepat, benar dan akurat.

2. E (Enuthusiasm): Melaksanakan pelayanan penuh gairah.

3. R (Reform): Memperbaiki kinerja pelayanan dari waktu ke waktu.

4. V (Value): Memberikan pelayanan yang mempunyai nilai tambah.

5. I (Impressive): Menampilkan diri secara menarik tetapi tidak berlebihan.

6. C (Care) : Memberikan perhatian atau kepedulian kepada pelanggan (nasabah) secara optimal.

7. E (Evaluation): Mengevaluasi pelaksanaan layanan yang sudah diberikan. ${ }^{21}$

Adapun karakteristik tentang pelayanan agar menjadi dasar bagaimana memberikan pelayanan yang terbaik, yaitu:

1. Pelayanan bersifat tidak dapat diraba, pelayanan sangat berlawanan sifatnya dengan barang jadi.

2. Pelayanan itu kenyataannya terdiri dari tindakan nyata dan merupakan pengaruh yang sifatnya adalah tindakan sosial.

3. Produksi dan konsumsi dari pelayanan tidak dapat dipisahkan secara nyata, karena pada umumnya kejadiannya bersamaan dan terjadi di tempat yang sama.

\section{Model SERVQUAL (Service Quality)}

SERVQUAL (Service Quality) merupakan model kualitas jasa (pelayanan) yang paling popular dan banyak dijadikan acuan riset manajemen dan pemasaran jasa, dikembangkan oleh Parasuraman, Zeithaml, dan Berry dalam serangkaian penelitian terhadap 6 sektor jasa: reparasi peralatan rumah tangga, kartu kredit, asuransi, sambungan telepon interlokal, perbankan ritel, dan pialang sekuritas.

${ }^{19}$ Fandy Tjiptono, Manjeman Pemasaran Perspfektif Asia terjemanhan buku Philip kotler (Yogyakarta: ANDI 2000), hlm. 134.

${ }^{20}$ Chambers, Essential Enghlish Dictionray (British: Harrap Publishers, 1995), hlm. 862.

${ }^{21}$ M. Nur Rianto Al Arif, Dasar-Dasar Pemasaran Bank Syariah (Bandung: CV Al fabeta, 2010), hlm. 212. 
Model servqual dikembangkan dengan maksud untuk membantu para manajer dalam menganalisis sumber masalah kualitas dan memahami cara-cara memperbaiki kualitas jasa. Model diilustrasikan pada gambar 2.1.

Gambar 2 Model servqual

Sumber: Fandy Tjiptono dan Gregorius Chandra, Service, Quality Satisfaction. ${ }^{22}$

Pelanggan

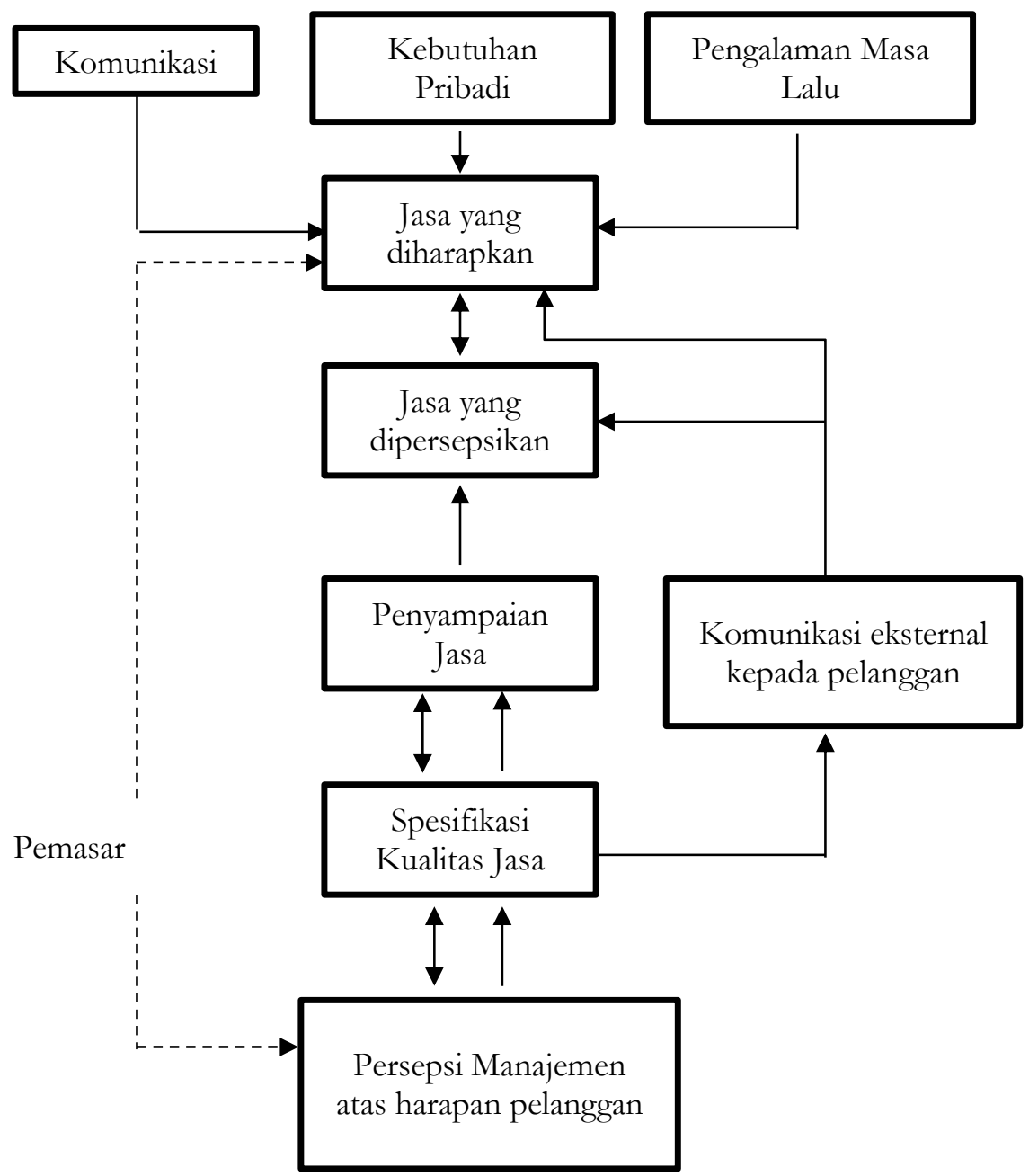

\section{Konsep Kualitas Pelayanan Dalam} Ekonomi Islam

Fasilitas dalam Islam dan konvensional juga tidak mengalami perbedaan yang signifikan, perbedaannya hanya terletak pada proses penggunaannya yang mana ketika pelaku bisnis memberikan pelayanan dalam bentuk fisik, yaitu dalam konsep Islam pelayanan yang berkenaan dengan tampilan fisik hendaknya tidak

\footnotetext{
${ }^{22}$ Fandy Tjiptono dan Gregorius Chandra, Service, Quality Satisfaction (2005), hlm. 146.

23 Muhsin Alhasani, Kualitas Pelayanan/Jasa Dalam Perspektif Islam, http://thedarkancokullujaba.blogspot.com/2010/12/
} kualitas-pelayanan-jasa-dalam.html, (8 November 2016) menonjolkan kemewahan (israf). ${ }^{23}$ Fasilitas yang membuat konsumen merasa nyaman memang penting, namun bukanlah fasilitas yang menonjolkan kemewahan. ${ }^{24}$ Pernyataan ini sebagaimana yang dinyatakan dalam Al Qur'an Surat At-Takaatsur ayat 1-5, yaitu:

${ }^{24}$ Ridwan Aldursanie, Kualitas Pelayanan dalam Islam, https://ridwan202.wordpress.com

/2013/02/11/kualitas-pelayanan-dalam-islam, 


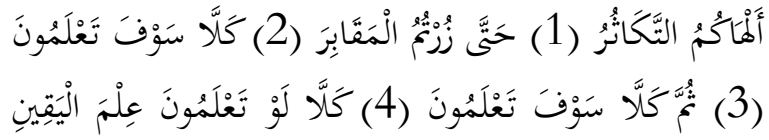

Artinya: "Bermegah-megahan telah melalaikan kamu, sampai kamu masuk ke dalam kubur., janganlab begitu, kelak kamu akan mengetahui (akibat perbuatanmu itu), dan janganlah begitu, kelak kamu akan mengetahui, janganlab begitu, jika kamu mengetabui dengan pengetabuan yang yakin"25

\section{Kajian Terdahulu}

Berdasarkan hasil penelusuran yang dilakukan peneliti, sejauh ini skripsi yang mengangkat permasalahan seperti ini belum ada, kalau pun ada tapi dari segi judul dan isinya memang berbeda. Adapun literatur yang berhubungan dengan penelitian ini:

1. Dra. Prima Naomi, MT menyimpulkan bahwa faktor yang pelaksanaannya telah sesuai dengan kepentingan dan harapan konsumen berjumlah sebelas faktor yaitu: pelayanan pemeriksaan yang cepat dan tepat, pelayanan perawatan yang cepat dan tepat, ketepatan jadwal pelayanan kunjungan perawat, kemampuan dokter untuk cepat tanggap dalam menyelesaikan keluhan pasien, kemampuan perawat untuk cepat tanggap dalam menyelesaikan keluhan pasien, keterampilan para dokter dalam bekerja, keterampilan dan kemampuan para perawat dalam bekerja, perhatian terhadap keluhan keluarga, pelayanan yang adil kepada semua pasien, kebersihan dan kerapihan ruangan dan kebersihan penampilan karyawan. Sedangkan faktor-faktor pelayanan kesehatan yang perlu diprioritaskan untuk diperbaiki adalah faktor prosedur penerimaan pasien yang cepat dan tepat, tindakan yang cepat dari yang dibutuhkan, pengetahuan dan kemampuan para dokter dalam menetapkan diagnosis penyakit, jaminan keamanan terhadap pasien, perhatian khusus dari dokter kepada setiap pasien, perhatian terhadap keluhan pasien, kelengkapan dan kesiapan alat-alat yang dipakai, kebersihan alat-alat yang dipakai. ${ }^{26}$

\footnotetext{
${ }^{25}$ Kementrian Agama RI, Ummul Mukminin AlQur'an dan Terjemah untuk wanita (Jakarta:Wali,2012), hlm. 35

26 Prima Naomi, Pengukuran Tingkat Kepuasan Pelanggan Terhadap Jasa Pelayanan Kesehatan (Menggunakan Metoda Performance Importance Analysis Di Unit Rawat Inap Rumah Sakit Umum Sumedang) (Jurnal-Universitas Winaya Mukti, Sumedang, tt). td.
}

Persamaan dengan penelitian penulis yaitu menggunakan Importance Performance Analysis sebagai metode menganalisis data yang diperoleh sedangkan perbedaanya adalah subjek dan obyek penelitian.

2. Muhammad Ibrohim menyimpulkan bahwa dari penelitian ini adalah (1) dilihat dari faktor harapan, nasabah menginginkan nilai bagi hasil harap ditinggikan, bukan tabungan wadi'ah saja yang menerapkan prinsip bagi hasil tetapi di produk lainnya juga diterapkan, Sumber Daya Manusia (SDM) yang berpengalaman dan profesional untuk menawarkan produk kepada masyarakat. (2) dilihat dari faktor kenyataan, nilai bagi hasil yang tidak meningkat, produk yang menerapkan prinsip bagi hasil hanya tertuju pada tabungan wadi'ah, SDM yang tidak berpengalaman dan profesional untuk menawarkan produk bahkan menjelaskan pun tidak bisa. (3) dilihat dari segi penggunaan akad, koperasi menggunakan akad penerapan prinsip bagi hasil syariah dimana setiap bulannya nasabah akan mendapatkan keuntungan bagi hasil dari koperasi. ${ }^{27}$ Persamaan dengan penelitian penulis yaitu menggunakan Importance Performance Analysis sebagai metode menganalisis data yang diperoleh sedangkan perbedaanya adalah sifat penelitian dimana penelitian ini menggunakan deskriftif kualitatif dan penelitian penulis menggunakan deskriftif kuantitatif.

3. Irwanullah menyimpulkan bahwa variabel kualitas pelayanan yang terdiri dari Daya Tanggap (X1), Kehandalan (X2), Jaminan (X3), Empati (X4) dan Bukti Fisik (X5) berpengaruh secara simultan terhadap kepuasan konsumen pada dealer resmi Yamaha Surya Prima A. Yani Banjarmasin. Hal ini dibuktikan dengan melihat pada nilai $\mathrm{F}$ hitung $>\mathrm{F}$ tabel $(27,256>2,31)$, sementara nilai Sig. yang diperoleh lebih kecil dari tingkat signifikansi yang telah ditetapkan $(0,000<0,05)$ yang artinya masih dalam batas toleransi yang telah ditentukan. Adapun secara simultan (uji t) didapatkan dari lima variabel yang memiliki pengaruh yang paling dominan diantara yang lainnya adalah variabel bukti fisik. Hal ini dibuktikan dengan melihat nilai Coefficientsa hasil uji koefisien regresi secara Parsial (uji t) yaitu 2,960.28 Persamaan penelitian

27 Muhammad Ibrohim, Importance Performance Analysis Terbadap Penerapan Prinsip Bagi Hasil Pada Koperasi Sababat Mandiri Unit Jasa Keuangan Syariah Di Kota Banjarmasin (SkripsiIAIN Antasari, Banjarmasin, 2016), td

${ }^{28}$ Irwanullah, Pengarub Kualitas Pelayanan Service Terhadap Kepuasan Konsumen Dealer Resmi Yamaha Surya Prima A. 
ini dengan penelitian penulis yaitu menggunakan variabel yang sama terhadap kualitas pelayanan service yang meliputi daya tanggap, kehandalan, jaminan, empati dan bukti fisik. Sedangkan perbedaanya adalah penelitian ini menggunakan alat analisis regresi linier berganda dengan uji simultan (uji f) dan parsial (uji t), penelitian penulis menggunakan Importance

Performance Analysis sebagai alat menganalisis data.

4. Muhammad Fazri menyimpulkan bahwa Pertama, variabel daya tanggap berhubungan positif/terdukung dengan variabel loyalitas, begitu pula variabel bukti fisik/nyata berhubungan positif/terdukung dengan variabel loyalitas, sedangkan variabel tingkah laku berhubungan negatif/tidak terdukung dengan loyalitas begitu pula dengan variabel kehandalan berhubungan negatif/tidak terdukung dengan loyalitas; Kedua, faktorfaktor yang mempengaruhi mahasiswa (i) dalam menggunakan jasa pelayanan Bank Kalsel Kedai Syariah IAIN Antasari Banjarmasin, ialah daya tanggap dan bukti fisik/nyata. ${ }^{29}$ Persamaan penelitian ini dengan penelitian penulis yaitu penelitian kuantitatif Sedangkan perbedaanya adalah penelitian ini menggunakan alat analisis regresi linier berganda dengan uji simultan (uji f) dan parsial (uji t), penelitian penulis menggunakan Importance Performance Analysis sebagai alat menganalisis data.

5. Yogi Wiryono menyimpulkan bahwa Risiko Hukum dalam pemberian kredit itu dapat terjadi baik dapat diindentifikasikan sebelumnya maupun tidak teridentifikasi sebelumnya yang disebabkan oleh beberapa hal yaitu Kelemahan aspek yuridis; Adanya perubahan hukum; Adanya kesalahan dalam kontrak, yang memberi dampak adanya tuntutan hukum yang dilakukan para stakeholders terhadap bank; dan adanya ketidakpastian legislasi, interprestasi, proses pengadilan, perbedaan peraturan dan kelengkapan dokumentasi yang dibutuhkan antar wilayah atau Negara yang dapat menimbulkan perselisihan. Untuk itu peran Sistem Informasi Debitur (SID) sangatlah

Yani Banjarmasin (Skripsi-IAIN Antasari, Banjarmasin, 2015), td.

${ }^{29}$ Muhammad Fazri, Pengarub Pelayanan Terhadap Loyalitas Nasabah Bank Kalsel Kedai Syariah IAIN Antasari Banjarmasin (Skripsi-IAIN Antasari, Banjarmasin, 2015), td

30 Yogi Wiryono, Tinjauan Normatif Sistem Informasi Debitur Sebagai Sistem Untuk Mengelola Risiko Hukum penting untuk mengelola risiko. hukum. ${ }^{30}$ Persamaan penelitian ini dengan penelitian penulis adalah mengkaji pelaksanaan pengelolaan Sistem Informasi Debitur. Sedangkan perbedaanya adalah penelitian ini menggunakan metode penelitian normatif, penelitian penulis menggunakan metode penelitian deskriptif.

\section{Kerangka Pemikiran}

Kerangka pemikiran dalam penelitian ini terbentuk dalam gambar dibawah ini:

Gambar 3

Kerangka Pemikiran

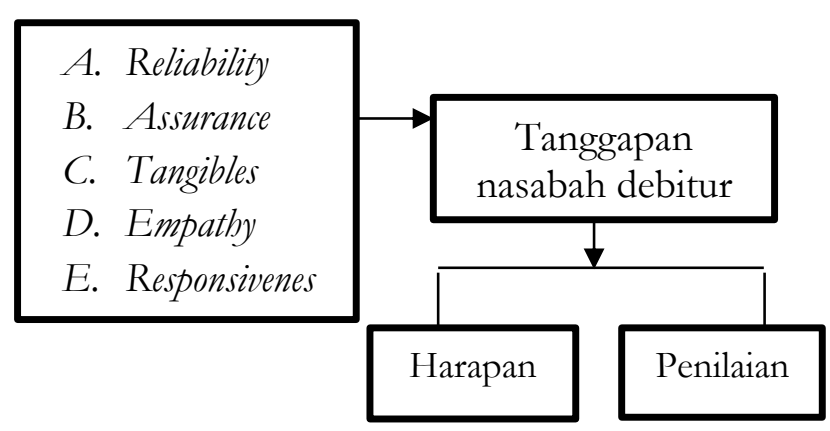

Sumber: J. Supranto, Pengukuran Tingkeat Kepuasan Pelanggan. ${ }^{31}$

\section{Metode Penelitian}

Jenis penelitian ini adalah penelitian lapangan (field research) dengan turun langsung ke lapangan untuk mendapatkan data-data yang diperlukan. Penelitian ini menggunakan pendekatan deskriptif kuantitatif, yaitu menekankan penjelasan mengenai analisis penilaian dan harapan nasabah debitur terhadap pelayanan permintaan Bank Indonesia. Penelitian deskriftif adalah penelitian yang berusaha untuk menuturkan pemecahan masalah yang ada berdasarkan data-data, menganalisis dan menginterpretasi. ${ }^{32}$

Penelitian kuantitatif mendapatkan statistik melalui penggunaan penelitian survei dalam skala besar, dengan menggunakan berbagai metode, seperti kuesioner atau wawancara. Penelitian kuantitatif banyak melibatkan orang, tetapi kontak

Perbankan (JurnalUniversitas Tanjungpura, Pontianak, 2013), td.

31 J. Supranto, Pengukuran Tingkat Kepuasan Pelanggan, 2006, hlm. 238.

32 Cholid Narbuko dan H.Abu Achmadi, Metodologi Penelitian (Jakarta: Bumi Aksara, 2001), hlm. 44. 
dengan orang-orang tersebut relatif jauh lebih cepat daripada dalam penelitian kualitatif. 33

Data yang dipergunakan dalam penelitian ini adalah data primer dan sekunder. Data primer merupakan data yang dikumpulkan langsung dari obyeknya dan diolah sendiri oleh suatu organisasi atau perorangan, sedangkan data sekunder ialah data yang diperoleh oleh suatu organisasi atau perusahaan dalam bentuk yang sudah jadi berupa publikasi. ${ }^{34}$

Populasi dalam penelitian ini adalah seluruh nasabah debitur yang datang ke Kantor Perwakilan Bank Indonesia Provinsi Kalimantan Selatan untuk mendapatkan pelayanan permintaan IDI Historis kepada pegawai Kantor Perwakilan Bank Indonesia Provinsi Kalimantan Selatan. Sedangkan sampel dalam penelitian ini adalah 39 orang nasabah debitur yang datang untuk mendapatkan pelayanan permintaan IDI Historis kepada pegawai Kantor Perwakilan Bank Indonesia Provinsi Kalimantan Selatan.

Untuk pemilihan sampel dalam penulisan penelitian ini menggunakan nonprobability sampling yaitu teknik pengambilan sampel yang tidak memberikan peluang/kesempatan sama bagi setiap unsur atau anggota populasi untuk dipilih menjadi sampel. ${ }^{35}$ Pengambilan sampel dilakukan dengan teknik sampling insidental, yaitu teknik penentuan sampel berdasarkan kebetulan, siapa saja yang secara kebetulan/incidental bertemu dengan peneliti dapat digunakan sebagai sampel. ${ }^{36}$ Adapun di dalam penilitian ini jumlah sampel ditentukan sebanyak 39 orang dari populasi nasabah debitur yang datang ke Kantor Perwakilan Bank Indonesia Provinsi Kalimantan Selatan untuk mendapatkan pelayanan permintaan IDI Historis kepada pegawai Kantor Perwakilan Bank Indonesia Provinsi Kalimantan Selatan.

\section{Teknik Analisis Metode Importance Performance Analysis}

Uji data menggunakan analisis kuadran atau Importance Performance Analysis (IPA) guna untuk menguji apakah terdapat kesenjangan (gap) antara Harapan dengan penilaian dalam variabel yang dianalisis. Uji dilakukan dengan membedakan nilai mean antara harapan dengan persepsi dan perbedaan tersebut berlangsung dalam kelompok sampel yang sama (pelanggan sama, mengisi kuesioner sama).

33 Catherine Dawson, Metode Penelitian Praktis (Yogyakarta: Pustaka Pelajar, 2010), hlm.16

${ }^{34}$ Supranto, Metode Ramalan Kuantitatif untuk Perencanaan Ekonomi dan Bisnis (Jakarta: Rineka Cipta, 2010), hlm.45.
Apabila persepsi nasabah debitur sesuai dengan atau melebihi standar yang diharapankan artinya tidak ada kesenjangan. Sebaliknya, apabila persepsi nasabah debitur lebih kecil daripada standar yang diharapkan artinya ada kesenjangan.

Rumus untuk menguji kesenjangan antara persepsi dan harapan nasabah debitur:

Keterangan:

$$
\begin{gathered}
\text { Gap }=\mathrm{X}-\mathrm{Y} \\
\text { dimana } \\
\mathrm{X}=\frac{\Sigma \mathrm{Xi}}{n} \quad \mathrm{Y}=\frac{\Sigma \mathrm{Yi}}{n}
\end{gathered}
$$

$\mathrm{Xi}$ : Skor tingkat kinerja

Yi : Skor tingkat harapan

$\mathrm{n}:$ Jumlah responden

Perbandingan performance dan importance dirangkum dalam diagram Cartesius yang tebagi atas empat kuadran. Sumbu mendatar adalah tingkat performance, sedangkan sumbu vertikal adalah tingkat importance. Kuadran pertama bercirikan performance rendah tetapi importance tinggi. Kuadran kedua, performance tinggi diikuti oleh importance yang tinggi pula. Kuadran ketiga, performance rendah dan importance juga rendah. Kuadran keempat performance tinggi tetapi importance rendah. Diagram Cartesius digunakan untuk melihat faktor-faktor yang penting atau yang menjadi prioritas utama untuk peningkatan pelayanan.

Tabel 2

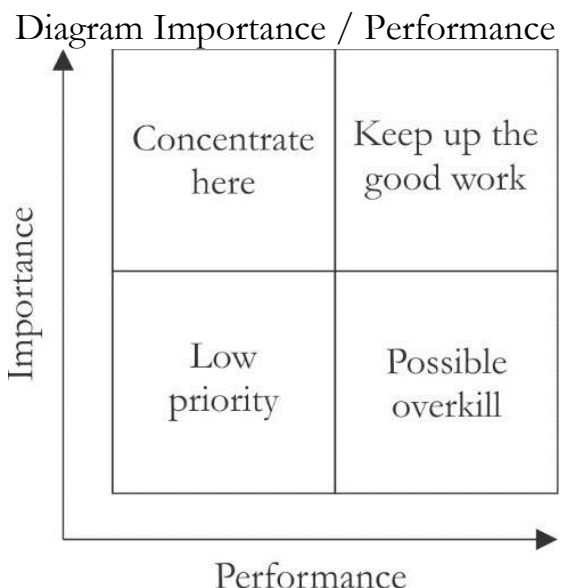

Sumber: John A. Martilla and John C. James, Importance Performance Analysis, Journal of Marketting, 1977, hlm. 78.

35 Sugiyono, Metode Penelitian Kuantitatif, Kualitatif, dan R\&DD (Bandung: Alfabeta, 2011), hlm. 84.

${ }^{36}$ Ibid., hlm.85. 
Kuadran I: Concentrate Here. ${ }^{37}$ Wilayah yang memuat faktor-faktor yang dianggap penting oleh pelanggan tetapi pada kenyataannya faktor-faktor ini belum sesuai seperti yang ia harapkan (tingkat kepuasan yang diperoleh masih sangat rendah). Variabel yang masuk dalam kuadran ini harus ditingkatkan.

Kuadran II: Keep Up The Good Work. Wilayah yang memuat faktor-faktor yang dianggap penting oleh pelanggan dan faktor-faktor yang dianggap sudah sesuai dengan yang dirasakannya. Varibel yang masuk dalam kuadran ini harus tetap dipertahankan karena semua variabel ini menjadikan jasa menjadi unggul.

Kuadran III: Low Priority. Wilayah yang memuat faktor-faktor yang dianggap kurang penting oleh pelanggan dan pada kenyataannya kinerjanya tidak terlalu istimewa. Peningkatan variabel yang masuk dalam kuadran ini dapat dipertimbangkan karena pengaruhnya terhadap pelanggan sangat kecil.
Kuadran IV: Possible Overkill. Wilayah yang memuat faktor-faktor yang dianggap kurang penting oleh pelanggan dan dirasakan terlalu berlebihan. Variabel dalam kuadran ini dapat dikurangi agar dapat menghemat biaya perusahaan.

\section{Pembahasan dan Hasil}

Analisis Diagram Cartesius Dengan menggunakan diagram Cartesius akan terlihat faktorfaktor mana yang penting atau yang menjadi prioritas untuk menghilangkan kesenjangan sehingga meningkatkan kualitas pelayanan. Berdasarkan nilai rata-rata pada tabel performance dan importance, di bawah ini akan dibentuk diagram Cartesius yaitu dengan menghubungkan nilai performance pada sumbu $\mathrm{X}$ dan nilai importance pada sumbu Y. sedangkan nilai rata-rata performance dan importance digunakan sebagai batas untuk menentukan kuadran I, II, III dan IV.

\section{Gambar 4.1 Diagram cartesius}

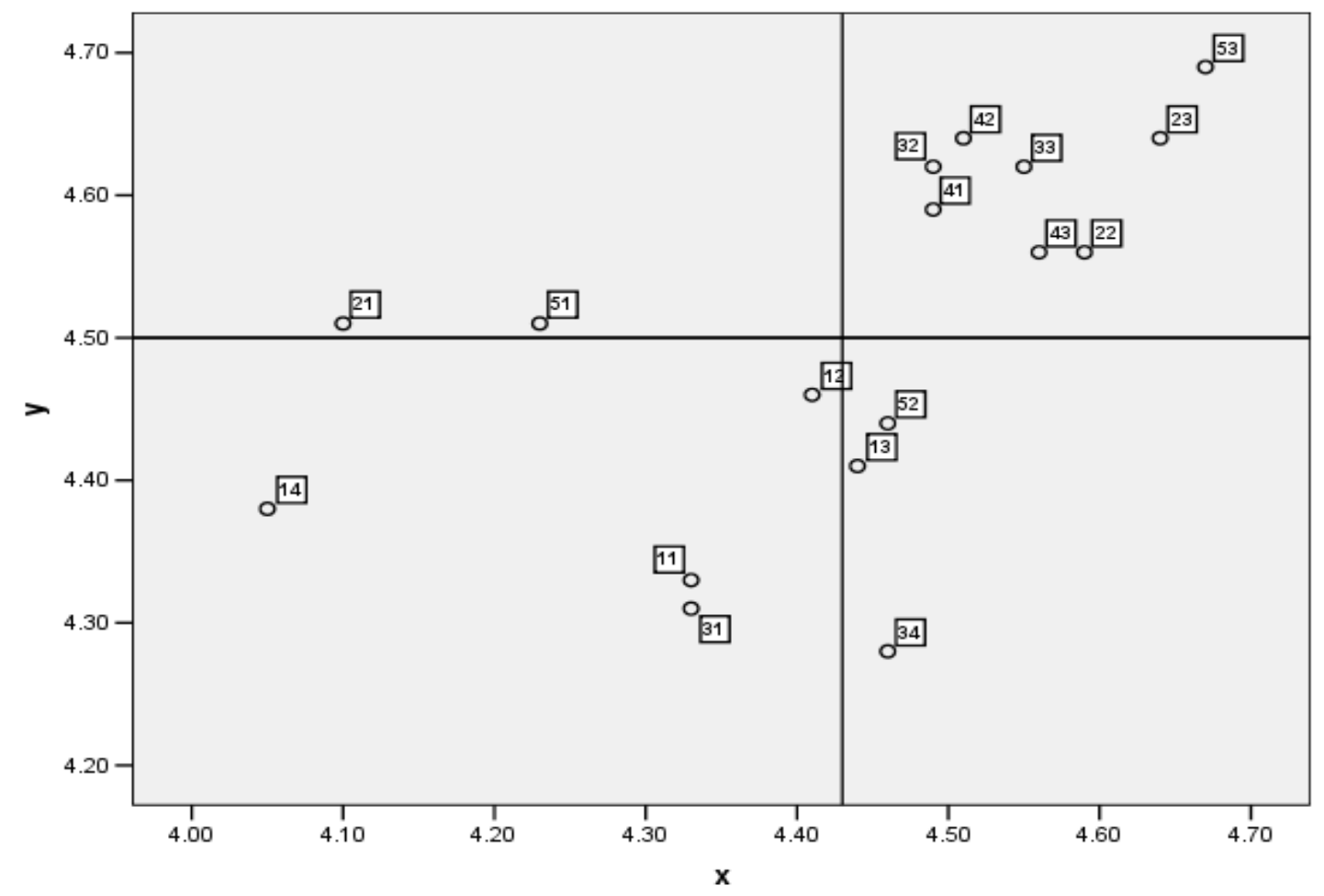

Sumber: Hasil penelitian 2016 (data diolah)

Berikut penjelasannya:

1. Kuadran I: Item pada level ini memiliki performance di bawah nilai performance rata-rata keseluruhannya $(4,43)$ tetapi tingkat kepentingannya berada di atas nilai importance rata-rata keseluruhan $(4,50)$. Importance

37 John A. Martilla and John C. James, Importance Performance Analysis (Journal of Marketting, January, 1977), hlm. 78. 
yang tinggi mencerminkan bahwa nasabah debitur mempunyai harapan yang tinggi pada item tersebut, tetapi pelayanan memiliki performance di bawah strandar Jadi item pada level ini perlu diprioritaskan untuk ditingkatkan. Dalam kuadran ini ada 2 item yang masuk yaitu:.

a. Item 21 (Pelayanan yang cepat)

Item ini memiliki performance 4,10 lebih rendah dari nilai performance rata-rata keseluruhan 4,43 tetapi tingkat importance 4,51 lebih tinggi dari nilai importance rata-rata keseluruhan.4,50.

b. Item 51 (Peralatan penunjang kemudahan dan kenyamanan yang memadai)

Item ini memiliki performance 4,23 lebih rendah dari nilai performance rata-rata keseluruhan 4,43 tetapi tingkat importance 4,51 lebih tinggi dari nilai importance rata-rata keseluruhan.4,50.

2. Kuadran II: Item pada level ini memiliki performance dan tingkat importance yang tinggi, performance dan importance dari item ini berada di atas tingkat performance dan importance rata -rata keseluruhan. Item yang berada pada level ini dianggap sudah sesuai dengan yang harapan nasabah debitur. Jadi item pada level ini harus tetap dipertahankan. Dalam kuadran ini ada 8 item yang masuk:

a. Item 22 (Petugas yang selalu bersedia membantu)

Item ini memiliki tingkat performance 4,59 lebih tinggi dari nilai performance rata-rata keseluruhan 4,43 dan tingkat importance yang tinggi pula 4,56 berada di atas nilai importance rata-rata keseluruhan. 4,50.

b. Item 23 (Petugas mampu menanggapi kebutuhan)

Item ini memiliki tingkat performance 4,64 lebih tinggi dari nilai performance rata-rata keseluruhan 4,43 dan tingkat importance yang tinggi pula 4,64 berada di atas nilai importance rata-rata keseluruhan.4,50.3)

c. Item 32 (Petugas yang menjaga rahasia)

Item ini memiliki tingkat performance 4,49 lebih tinggi dari nilai performance rata-rata keseluruhan 4,43 dan tingkat importance yang tinggi pula 4,62 berada di atas nilai importance rata-rata keseluruhan.4,50.

d. Item 33 (Petugas yang bersikap sopan dan ramah)

Item ini memiliki tingkat performance 4,55 lebih tinggi dari nilai performance rata-rata keseluruhan 4,43 dan tingkat importance yang tinggi pula 4,62 berada di atas nilai importance rata-rata keseluruhan 4,50.

e. Item 41 (Petugas yang penuh perhatian)
Item ini memiliki tingkat performance 4,49 lebih tinggi dari nilai performance rata-rata keseluruhan 4,43 dan tingkat importance yang tinggi pula 4,59 berada di atas nilai importance rata-rata keseluruhan 4,50.

f. Item 42 (Petugas bersungguhsungguh melayani)

Item ini memiliki tingkat performance 4,51 lebih tinggi dari nilai performance rata-rata keseluruhan 4,43 dan tingkat importance yang tinggi pula 4,64 berada di atas nilai importance rata-rata keseluruhan.4,50

g. Item 43 (Petugas mampu memahami kebutuhan)

Item ini memiliki tingkat performance 4,56 lebih tinggi dari nilai performance rata-rata keseluruhan 4,43 dan tingkat importance yang tinggi pula 4,56 berada di atas nilai importance rata-rata keseluruhan.4,50.

h. Item 53 (Dokumen yang tercetak dengan baik/jelas)

Item ini memiliki tingkat performance 4,67 lebih tinggi dari nilai performance rata-rata keseluruhan 4,43 dan tingkat importance yang tinggi pula 4,69 berada di atas nilai importance rata-rata keseluruhan.4,50.

3. Kuadran III: Item pada level ini memiliki performance dan tingkat importance yang samasama berada di bawah strandar rata-rata item keseluruhan. Item pada level ini dianggap kurang penting oleh nasabah debitur dan pada kenyataannya kinerjanya tidak terlalu istimewa. Dalam kuadran ini ada 4 item yang masuk yaitu:

a. Item 11 (Transparansi (keterbukaan) didalam pelayanan terkait data/informasi

Item ini memiliki tingkat performance 4,33 lebih rendah dari nilai performance rata-rata keseluruhan 4,43 namun tingkat importance 4,33 lebih rendah juga dari nilai importance ratarata keseluruhan 4,43.

b. Item 12 (Petugas yang memiliki sifat dapat diandalkan)

Item ini memiliki tingkat performance 4,41 lebih rendah dari nilai performance rata-rata keseluruhan 4,43 namun tingkat importance 4,46 lebih rendah juga dari nilai importance ratarata keseluruhan 4,43.

c. Item 14 (Petugas memberikan pelayanan informasi secara benar sejak pertama kali) Item ini memiliki tingkat performance 4,05 lebih rendah dari nilai performance rata-rata keseluruhan 4,43 namun tingkat importance 4,38 lebih rendah juga dari nilai importance ratarata keseluruhan 4,43.

d. Item 31 (Petugas yang dapat dipercaya) 
Item ini memiliki tingkat performance 4,33 lebih rendah dari nilai performance rata-rata keseluruhan 4,43 namun tingkat importance 4,31 lebih rendah juga dari nilai importance rata-rata keseluruhan 4,43.

4. Kuadran IV: Item pada level ini memiliki tingkat performance yang baik berada di atas performance rata-rata keseluruhan, tetapi item ini dianggap tidak penting dimana tingkat importance rendah. Dalam kuadran ini ada 3 item yang masuk yaitu:

a. Item 13 (Petugas memberikan pelayanan informasi secara benar sejak pertama kali)

Item ini memiliki tingkat performance 4,44 lebih tinggi dari nilai performance rata-rata keseluruhan 4,43 sedangkan tingkat importance 4,41 lebih rendah dari nilai importance rata-rata keseluruhan 4,50.

b. Item 34 (Petugas yang kompeten dibidangnya)

Item ini memiliki tingkat performance 4,46 lebih tinggi dari nilai performance rata-rata keseluruhan 4,43 sedangkan tingkat importance 4,28 lebih rendah dari nilai importance rata-rata keseluruhan 4,50.

c. Item 52 (Petugas berpakaian dan berpenampilan rapi)

Item ini memiliki tingkat performance 4,46 lebih tinggi dari nilai performance rata-rata keseluruhan 4,43 sedangkan tingkat importance 4,44 lebih rendah dari nilai importance rata-rata keseluruhan 4,50.

Berdasarkan hasil penelitian ini, performance yang merupakan penilaian oleh nasabah debitur dan tingkat importance yang merupakan harapan dari nasabah debitur dapat dijadikan alat untuk mengukur kualitas pelayanan IDI Historis Pada Kantor Perwakilan Bank Indonesia Provinsi Kalimantan Selatan, yang selama ini tidak memiliki strandar pelayanan sehingga sulit untuk mengukur kualitasnya.

Hasil analisis menunjukan bahwa pelayanan Permintaan IDI Historis Pada Kantor Perwakilan Bank Indonesia Provinsi Kalimantan Selatan yang diberikan oleh petugas Bank Indonesia menunjukan kesenjangan antara harapan dan penilaian nasabah debitur. Rata-rata performance keseluruhan item variabel memiliki nilai sebesar 4,43 lebih kecil dari nilai rata-rata tingkat

\footnotetext{
38 Sutopo, Adi Suryanto, Pelayanan prima (Jakarta: LAN, 2006), hlm. 6

39 Ridwan Aldursanie, Kualitas Pelayanan dalam Islam, https://ridwan202.wordpress.com

/2013/02/11/kualitas-pelayanan-dalam-islam, November 2016) importance keseluruhan item variabel dengan nilai sebesar 4,50.

Berdasarkan teori, pelayanan disebut sangat baik atau akan menjadi prima, manakala dapat atau mampu memuaskan pihak yang dilayani (pelanggan). Dalam hal ini pelayanan disebut prima jika sesuai dengan harapan pelanggan. ${ }^{38}$ Sedangkan pelayanan yang diberikan oleh petugas Sistem Informasi Debitur Pada Kantor Perwakilan Bank Indonesia Provinsi Kalimantan Selatan.belum memenuhi harapan nasabah debitur yang datang dengan tujuan mendapatkan pelayanan Permintaan IDI Historis.

Berdasarkan penjelasan dalam teori pelayanan menurut Islam, dimensi assurance (jaminan) berkenaan dengan pengetahuan atau wawasan, kepercayaan dari pemberi layanan, garansi, serta respect terhadap konsumen. Apabila pemberi layanan menunjukkan sikap respect dan meyakinkan maka akan meningkatkan persepsi positif dan nilai bagi konsumen terhadap lembaga penyedia jasa. ${ }^{39}$

Hasil penelitian menunjukan variabel assurance (jaminan) memiliki nilai rata-rata tingkat kinerja yang sama dengan nilai rata-rata tingkat kepentingan khususnya pada item pernyataan petugas yang dapat dipercaya dan item pernyataan petugas yang kompetan dibidangnya memiliki nilai rata-rata tingkat kinerja lebih dari nilai rata-rata tingkat kepentingan. Namun demikian, masih terdapat ruang untuk lebih mengoptimalkan kualitas assurance (jaminan) dengan meningkatkan kualitas petugas yang dapat dipercaya dan petugas yang bersikap sopan dan ramah.

Konsep pelayanan dalam persfektif Islam menyatakan bahwa bukti fisik merupakan tampilan fisik yang akan menunjukkan identitas organisasi sekaligus faktor pendorong munculnya persepsi awal pelanggan terhadap suatu organisasi jasa. Ketidakmampuan organisasi dalam menampilkan bukti fisiknya dengan baik, akan melemahkan citra serta dapat menciptakan persepsi negatif pada pelanggan. ${ }^{40}$ Hasil penelitian, menunjukan variabel tangible memiliki nilai rata-rata tingkat kinerja yang sama dengan nilai rata-rata tingkat kepentingan dan terdapat satu item pada variabel tangible (bukti fisik) yang memiliki nilai rata-rata tingkat kinerja lebih besar dari nilai rata-rata tingkat kepentingan yaitu petugas yang berpakaian dan berpenampilan rapi.

\footnotetext{
40 Ridwan Aldursanie, Kualitas Pelayanan dalam Islam, https://ridwan202.wordpress.com

/2013/02/11/kualitas-pelayanan-dalam-islam, November 2016).
} 
Namun terdapat dua item pernyataan yang memiliki nilai rata-rata tingkat kinerja lebih besar dari nilai rata-rata tingkat kepentingan yaitu item pernyataan peralatan penunjang kemudahan dan kenyamanan pelayanan dan dokumen yang tercetak dengan baik/jelas. Bahkan salah satu item variabel masuk ke dalam kuadran I yaitu item pernyataan peralatan penunjang kemudahan dan kenyamanan pelayanan.

Oleh karena itu, bukti fisik ini menjadi salah satu faktor pendorong kesenjangan antara harapan dan penilaian nasabah debitur sehingga pelayanan Permintaan IDI Historis Pada Kantor Perwakilan Bank Indonesia Provinsi Kalimantan Selatan belum bisa dikatakan sebagai pelayanan prima.

Kemudian, sikap empati akan membuat konsumen merasa kebutuhannya terpuaskan karena dirinya dilayani dengan baik. Kesediaan memberikan perhatian dan membantu akan meningkatkan persepsi dan sikap positif konsumen terhadap layanan perusahaan. Hal ini yang akan mendatangkan kesukaan, kepuasan dan meningkatkan loyalitas konsumen.

Hasil penelitian menunjukan satu item yang terdapat pada variabel empathy (empati) memiliki nilai rata-rata tingkat kinerja telah sesuai dengan nilai rata-rata tingkat kepentingan yaitu item pernyataan petugas mampu memahami kebutuhan. Namun dua item pernyataan yaitu petugas yang penuh perhatian dan petugas bersungguh-sungguh melayani memiliki nilai rata-rata tingkat kinerja lebih rendah dari nilai rata-rata tingkat kepentingan. Petugas Sitem Informasi Debitur beum dapat memenuhi harapan terkait kualitas empathy dalam pelayanan permintaan IDI Historis, sehingga belum secara optimal mendorong peningkatan persepsi dan sikap positif konsumen terhadap perusahaan.

Berdasarkan teori kualitas pelayanan menurut ilmu ekonomi Islam, kehandalan merupakan inti dari kualitas jasa, karena pelanggan menilainya berdasarkan pengalaman dalam menggunakan jasa tersebut.

Hasil penelitian menunjukan bahwa pada variabel reliability (kehandalan) memiliki nilai ratarata tingkat kinerja lebih rendah dari nilai rata-rata tingkat kepentingan khususnya pada item pernyataan petugas yang memiliki sifat dapat diandalkan dan item pernyataan komitmen waktu tunggu dari petugas . Dengan demikian, kualitas pelayanan belum bisa dikatakan baik atau prima karena sifat yang dapat diandalkan dari petugas mendapat penilaian yang rendah dari nasabah debitur berdasarkan pengalaman dalam menggunakan pelayanan tersebut. Namun item pernyataan petugas yang memiliki sifat dapat diandalkan memiliki tingkat kesenjangan yang rendah rendah tidak termasuk prioritas yang harus diperbaiki.

Teori Islam juga menjelaskan bahwa daya tanggap merupakan bagian dari profesionalitas. Organisasi yang profesional senantiasa berkomitmen untuk memberikan pelayanan terbaik, memperhatikan harapan dan masukan dari pelanggan serta meresponnya dengan cepat dan tepat.

Jika melihat pada hasil penelitian, terdapat satu item yang sesuai, satu item melebihi harapan dan satu item di bawah harapan. Dapat disumpulkan bahwa hal yang perlu ditingkatkan adalah pelayanan yang cepat untuk memberikan daya tanggap petugas yang lebih baik.

\section{Kesimpulan}

Berdasarkan data dan analisis yang diuraikan pada bab sebelumnya, dapat ditarik kesimpulan bahwa dengan menggunakan metode Importance Performance Analysis diketahui kualitas pelayanan permintaan Informasi Debitur Individual (IDI) Historis Pada Kantor Perwakilan Bank Indonesia Provinsi Kalimantan Selatan belum seluruhnya memenuhi kriteria pelayanan prima karena secara rata-rata keseluruhan item variabel masih terdapat kesenjangan antara nilai rata-rata tingkat kinerja/performance dengan nilai rata-rata tingkat kepentingan/importance.

Berdasarkan lima variabel yang dinilai oleh responden, dua variabel menunjukan kondisi tingkat kinerja pelayanan telah sesuai dengan tingkat kepentingan. Namun demikian, tiga variabel lainnya menunjukkan kesenjangan dimana nilai rata-rata tingkat kinerja lebih kecil dari nilai rata-rata tingkat kepentingan yaitu variabel reliability, responsiveness, dan tangibles.

Dengan menggunakan diagram Cartesius terlihat faktor-faktor yang penting atau yang menjadi prioritas untuk menghilangkan kesenjangan sehingga meningkatkan kualitas pelayanan. Faktorfaktor pelayanan yang perlu diprioritaskan untuk diperbaiki adalah Item 21 (Pelayanan yang cepat) dan Item 51 (Peralatan penunjang kemudahan dan kenyamanan yang memadai).

\section{Referensi}

Al Arif, M. Nur Rianto. 2010. DasarDasar Pemasaran Bank Syariah. Bandung: CV Al fabeta.

Aldursanie, Ridwan. Kualitas Pelayanan dalam Islam. https://ridwan202.wordpress.com /2013/02/11/kualitas-pelayanandalamislam, (8 November 2016).

Alhasani, Muhsin. Kualitas Pelayanan/Jasa Dalam Perspektif

Islam. 
http://thedarkancokullujaba.blogspot. com/2010/12/kualitas-pelayananjasadalam.html, (8 November 2016)

Chambers. 1995. Essential Enghlish Dictionray. British: Harrap Publishers

Dawson, Catherine. 2010.Metode Penelitian Praktis, Penerjemah M. Widiono \& Saifuddin Zuhri Qudsy. Yogyakarta: Pustaka

Pelajar. Fazri, Muhammad. Pengarub Pelayanan Terhadap Loyalitas Nasabah Bank Kalsel Kedai Syariah LAIN Antasari Banjarmasin (SkripsiIAIN Antasari, Banjarmasin, 2015), td.

Ibrohim, Muhammad. Importance Performance Analysis Terhadap Penerapan Prinsip Bagi Hasil Pada Koperasi Sababat Mandiri Unit Jasa Keuangan Syariab Di Kota Banjarmasin (Skripsi-IAIN Antasari, Banjarmasin, 2016), td.

Irwanullah, Pengaruh Kualitas Pelayanan Service Terbadap Kepuasan Konsumen Dealer Resmi Yamaha Surya Prima A. Yani Banjarmasin (Skripsi-IAIN Antasari, Banjarmasin, 2015), td.

Kementrian Agama RI. 2012. Ummul Mukminin AlQur'an dan Terjemah untuk wanita. Jakarta:Wali.

Latumaerissa, Julius R. 2011. Bank dan Lembaga Keuangan Lain. Jakarta: Salemba Empat.

Manurung, Jonni. 2009. Ekonomi Keuangan dan Kebijakan Moneter. Jakarta: Salemba Empat.

Martilla, John A. and John C. James. 1977. Importance Performance Analysis. Journal of Marketing.

Naomi, Prima. tt. Pengukuran Tingkat Kepuasan Pelanggan Terbadap Jasa Pelayanan Kesehatan (Menggunakan Metoda Performance Importance Analysis Di Unit Rawat Inap Rumah Sakit Umum Sumedang.) JurnalUniversitas Winaya Mukti, Sumedang.

Narbuko, Cholid dan H.Abu Achmadi. 2001. Metodologi Penelitian. Jakarta: Bumi Aksara.

Rangkuti, Freddy. 2002. Measuring Customer Statisfaction Teknik Mengukur dan Strategi
Meningkatkan Kepuasan Pelanggan. Jakarta: Gramedia Pustaka Utama.

Rivai, H. Veithzal. 2013. Commercial Bank Management: Manajemen Perbankan dari Teori ke Praktik. Jakarta: Rajawali Pers.

Sipayung, Marini. BI Dorong Pemanfaatan Sistem Informasi Debitur. Bengkulu: Antara Bengkulu, 2015.http://m.antarabengkulu.com/berit a/31739/bi-dorong-pemanfaatan sisteminformasi-debitur (26 Maret 2016).

Siregar, Pulo. 2014. Bebaskan utangmu 27 Studi Kasus Menyelesaikan Utang Secara Legal. Jakarta: Kompas Gramedia.

Sugiyono. 2011. Metode Penelitian Kuantitatif, Kualitatif, dan R\&D. Bandung: Alfabeta.

Sulhan, M. dan Ely Siswanto. 2008. Manajemen Bank Konvensional dan Syariah. Malang: UINMalang Press.

Supranto, J. 2006. Pengukuran Tingkat Kepuasan Pelanggan. Jakarta: Rineka Cipta.

Supranto. 2010. Metode Ramalan Kuantitatif untuk Perencanaan Ekonomi dan Bisnis. Jakarta: Rineka Cipta. Susanto. 2002. Kamus Istilah Pemasaran. Jakarta: PT Gramedia.

Sutopo dan Adi Suryanto. 2006. Pelayanan prima. Jakarta: LAN. Teguh, Hendra dan Ronny A. Rusli. 1997. Manajemen Pemasaran, Manajemen Pemasaran jilid 2 terjemahan resmi dari buku Philip Kotler, Marketing Managemet, Jakarta: Prenhallindo.

Tjiptono, Fandi dan Gregorius Chandra. 2005. Service, Quality \&o Statisfaction. Yogyakarta: Andi, 2005

Tjiptono, Fandy. 2002. Manjeman Pemasaran Perspfektif Asia terjemanhan buku Philip kotler. Yogyakarta: Andi.

Wiryono, Yogi. Tinjanan Normatif Sistem Informasi Debitur Sebagai Sistem Untuk. Mengelola Risiko Hukum Perbankan (Jurnal-Universitas Tanjungpura, Pontianak, 2013), td. 